\title{
地下水数值計算法（16） 講座を終えるに当たって
}

\author{
藤崎克博 $*$. 神野健二 $* *$
}

\section{1.はじめに}

本講座では、地下水流動解析のための有限要素法 (講座 $\langle 2\rangle \sim<5>$ )、差分法 (講座 $\langle 6>$ 、 $<$ $7>$ )、境界要素法 (講座 $<8>、<9>$ ) と、物 質輸送解析のための特性曲線法（講座 $\langle 10>、<11$ $>$ )、特性曲線型有限要素法 (講座 $\langle 12>、<13>$ )、 拉よびパラメー夕逆同定のためのカルマンフィル ター法 (講座 $<14>$ )、パウエル法 (講座 $<15>$ ) について解説した。地下水数值計算法の現状につい て、最新の話題を含めて、ほぼ網羅し得たものと思っ ている。

講座を終えるにあたって、それぞれの分野につい て総括し、問題点をとりまとめ、今後の展望につい て述べてみる。

\section{2. 地下水流動解析について}

地下水流動解析の内、飽和流の解析手法について は完成の域にあるといえよう。飽和・不飽和流につ いても、手法的には完成の域に近いが、不均一な現 場の不飽和透水係数をどのように測定するかといっ たパラメータの決定の問題が残されている。手法的 には、大規模な 3 次元の問題をいかに効率的に解く かといったこともある（西垣他、1990）。

差分法、有限要素法、境界要素法のどれがよいか という問題は、それぞれに一長一短があり、どれが 絶対的に優れているとはいえず、それぞれの場面で 条件に合った方法を選べばよいといえよう。

\footnotetext{
*地質コンサルタント

**九州大学工学部 水工土木学科
}

数值モデルを適用する場合、注意すべき点は、モ デルに合わせて地質・地下水の解析をするのではな く、現地の水文地質構造にあわせたモデルを選定す べきことである。最初に、いたずらに複雑なモデル を選んでしまうと、それに合わせた十分なデータを 現地で得ることができないで、推定值を用いざるを えないことが多く、結果的には精度の低い成果しか 得ることができないことになる。

まず、地質と地下水の組み合わせからなる水文地 質構造を解析することが、最優先されなければなら ない。すなわち、砂層や砂砅層からなる带水層と粘 土・シルト層からなる難透水層の分布を明らかに し、その水理特性を明らかにして、地下水の流動状 況を解明することから始める。この段階で、モデル 構造が決定され、そして解析が成功するかしないか が決定されるといっても過言でなく、十分な知識と 経験が必要とされる。

つぎに、水文地質構造と解析の目的を考え合わせ て、モデルを決定する。水文地質構造のモデル化の 過程については、水収支研究グループ（1976）など を参考にされたい。モデルは、空間（1 次元から 3 次元)、時間 (定常、非定常)、地下水流動（飽和、 不飽和）の組み合わせでさまざまなものが考えられ る。それらの中で、目的を達成できる範囲のもっと もシンプルなものを選択するのが、成功率が高い。 モデルを精密化することによって得られる精度向上 より、新たな不確定パラメータを導入することによ る精度低下の方が大きいためである。

実際に解析に用いる数值モデルは、国際地下水モ デリングセンター*の分類によると、表一 1 のよう に数多くのものがある。パソコンで使用できるもの も多く、市販されているものもある。本学会でも、 


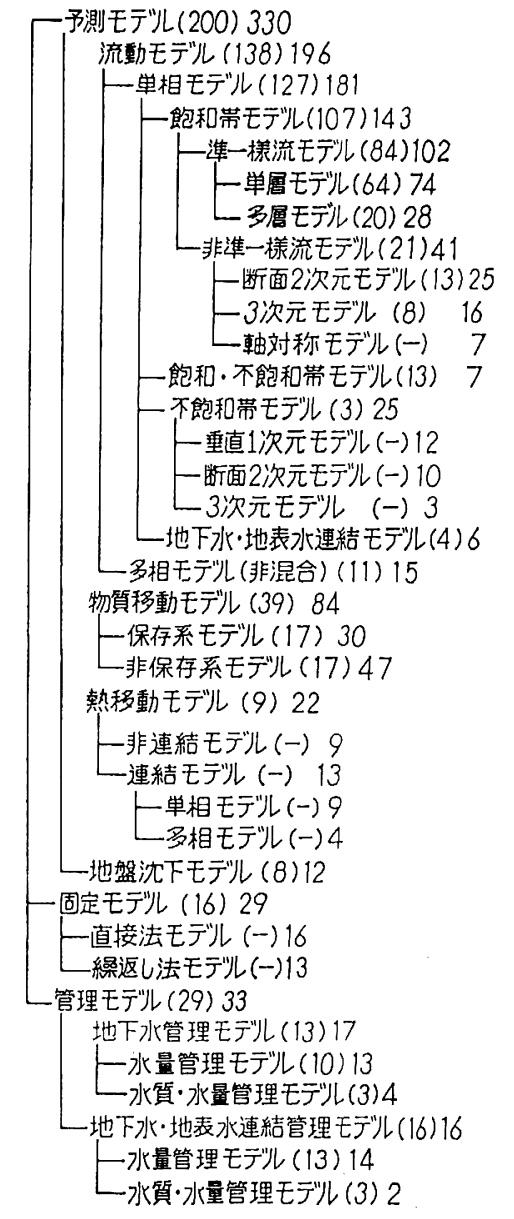

注)数字はモデル数、( )内は1978年のモデ数。

表ー 1 地下水モデルの区分（1984年現在）(藤縄・

藤崎、1987より)

数值計算法の普及を考えて、シミュレーション講習 会を開催している。

\section{3. 物質輸送解析について}

近年、地盤沈下に替わって地下水を脅かすものと して、地下水污染が問題となっている。この内、地 下水に溶けて移動する混合性物質の輸送問題につい
ては、実用化されており、国内での報告例もいくつ かある（古市他、1990; 古野他、1991）。その基礎 となる移流分散方程式の数值解法としては、特性曲 線法が数值分散をおこさないため、差分法あるいは 有限要素法と組み合わされて用いられている。同様 に、数值分散を避けることのできるランダムウォー ク法も、簡単で視覚的であるため用いられている。

移流分散方程式に使われる分散係数は、分散能係 数（dispersivity）と平均間隙流速の積で表される。 分散能係数には、測定のスケールで大きく異なると いうスケール依存性が認められる (Pickens and Grisak, 1981）。しかし、理論的な検討結果からは、 污染源から遠距離になるか長い経過時間を経れば、 分散能係数は一定值に近づき (Anderson，1984)、 この場合には流移分散方程式が適用できる。

污染現象は、このように、地下水流動に比べて複 雑である。このため、水文地質構造についても、地 下水流動の場合に較べてより細かい解明が必要とな る（榆井他、1991）。地下水流動の場合には部層単 位程度の区分でよいものが、単層から薄層の単位ま で区分しなければならなくなる。また、地下水流動 機構の解明の度合いも、格段に精度高くおこなう必 要がある。すなわち、污染物質の移動は地下水流速 に大きく依存するが、これが不正確であれば、ある 時点の污染濃度分布に合わせてモデルの検証をした としても、予測の段階で大きくずれてくるからであ る。

最近、有機塩素系溶剤のような揮発性物質による 不飽和带の污染除去方法として、地下空気を強制的 に吸引・排気する真空抽出法が注目されている。こ のための解析方法も開発されているが (Johnson et al., 1990 ; 佐藤・榆井、1991)、今後の現地への適 用にともなって進展がみられるものと思われる。

非混合性物質の場合は、多相流となるため、混合 性物質の場合に較べてより複雑になる。このため、 現在のところ、実際例はまだ少ない。今後の研究の 発展が望まれる分野である。

物質輸送解析は、地下水流動解析に比べて、計算 の安定性基準からより細かいメッシュ区分を必要と する。このため、3 次元などの大規模な問題になる

\footnotetext{
*International Ground Water Modeling Center, Institute for Ground-water, Research and Education, Colorado School of Mines, Gol. den, Colorado 80401-1887 USA

地下水モデルの収集、分類、販売、研修などを行っており、表一1の各モデルもここで入手することができる。
} 
と、大計算機容量と長大な計算時間を必要とするこ とになる。したがって、効率的な計算のためには、 前処理付き共役勾配法などの特殊な反復解法が必要 となってくる(村田他、1990)。また、並列処理によっ て効率を高めることも考えられる（矢川・曽根田、 1991）。並列処理は、ベクトル計算機のような大型 計算機ばかりでなく、最近ではパソコンレベルでも 可能になっている（山本他、1990）。

\section{4. パラメータ逆同定・その他について}

パラメー夕逆同定は、地下水位測定值から透水

(量) 係数などの最適パラメー夕を逆に算定するも ので、数学的には逆問題とよばれる。1970年代から さまざまなす法が開発されている（Yeh, 1986のレ ビゥーなどを参照されたい）。

揚水試験のデー夕から透水量係数などを算定する 簡単なものについては実用化されている（藤崎、 1988 ; キンツェルバッハ、1990)。しかし、分布パ ラメー夕を逆算する複雑な場合については、いまだ 問題が残されている。これは、観測值に含まれる計 測誤差などの誤差が、逆算されるパラメータに大き くはね返るためである。

したがって、この点に十分注意しないと、非現実 的なパラメー夕を得ることになる。また、最適なパ ラメータが算定されるというのは、設定したモデル に対して、モデル出力が実測值ともっともよく適合 するようにパラメータが選定されるという意味で あって、“最適なモデル”が保障されるのではない ことに注意する必要がある。

最適化の手法は、揚水量の最適配分のような問題 にも適用される（藤崎、1988）。この場合にも、最 適とは与えられた制約条件に対する数学的な最適性 をいっているだけであることに注意する必要があ る。

\section{5. 参考書について}

地下水の数值計算法の参考書は、各回の講座にも 示されているが、代表的なものをとりまとめて次に 紹介する。さらに勉強をしたいという方々の参考に なれば幸いである。

1 ) Remsom et al. (1971)：差分法による飽和流か ら不飽和流の計算法を基礎から解説している。実例
は、全く示されてない。

2 ) 水収支研究グループ (1976)：広域地下水盆の モデル化、パラメータの抽出、モデルの同定抢よび 予測について、実際例をあげながら説明している。 差分法の FORTRAN プログラムもついている。

3 ) Pinder and Gray (1977): 有限要素法の基礎か ら塩水化の解析の応用まで述べている。実例は多く ないが、豊富な文献リストがついている。

4 ) コーナー・ブレビア (1978)：有限要素法によ る基碟的な計算法を、簡単な FORTRAN プログラ ムとともに解説してある。

5 ）ブレビア（1980）：境界要素法の基礎が、 FORTRAN プログラムとともに解説してある。

6 ) ッィエンキーヴィッ（1984）: 有限要素法の基 礎から応用までを扱った代表的な教科書である。構 造力学から基礎工学まで幅広い分野を取り扱ってい る。なお、有限要素法に関する教科書は、これ以外 に数多く出版されている。

7 ) Bear and Verruijt (1987)：地下水流動㧍よび 物質輸送問題について、簡単なBASIC プログラム を用いて説明している。

8 ) フヤコーン・ピンダー (1988) : 有限要素法の ほかに差分法やその他の特殊技法について述べてあ り、地下水流動、物質輸送、エネルギー輸送問題の 解析法を解説してある。実例はないが、文献リスト が役立つ。

9) Celia at al. eds. (1988)：第 7 回水資源に扔け る有限要素法解析国際会議の講演集である。2 年毎 に同名の会議が開かれていて、講演集が出版されて いる。最新のトピックスを検索するには最適である。 10)キンツェルバッハ(1990): 地下水流動、パラメー 夕逆同定、最適化問題拉よび物質輸送について簡単 なBASICプログラムを示しながら、やさしく解説 してある。プロッピーディスクも販売されている。

これら以外にも、数多くの数值計算法の参考書が 出版されている。また、英文雑誌・学会誌では、 Water Resources Research (AGU)、Journal of Hydrology (Elsevier)、Groundwater (NWWA) など、邦文 では、本学会誌、土木学会論文集、土質工学会論文 報告集、農業土木学会論文集などに最新の情報が載 せられているので参考にされたい。 


\section{参考文献}

W．キンツェルバッハ〔上田年比古監訳〕（1990）：『パソ コンによる地下水解析』森北出版、286p.

J.J. コナー・C.A.ブレビア〔奥村敏惠監訳〕(1978)：『流 体解析への有限要素法の応用』サイエンス社、232p.

佐藤賢司・榆井 久 (1991)：地下水空気の流動シミュレー ションについて、第 1 回環境地質学シンポジウム講演論 文集、103 106.

O.C. ツィエンキーヴィッッ〔吉識雅夫・山田嘉昭監訳〕 （1984）：『マトリックス有限要素法三訂版』培風餙、 $817 \mathrm{p}$.

西垣 誠・白石知成·猪瀬二郎・川村志郎 (1990)：地下 鉄建築による多層地盤での複数地下水变動の 3 次元浸透 解析による予測、地下水学会誌、32-4、231 240.

榆井 久他（1991）：地下水污染調査の基本、『地下水污染 論』共立出版、120 153.

藤崎克博 (1988)：揚水試験デー夕の自動解析、地下水と 井戸とポンプ、32-8、1 7.

藤崎克博（1989）：地盤沈下（6)、地盤沈下の解析（その 2 )、地下水学会誌、31-1、39４4.

藤縄克之・藤崎克博 (1987) : 地下水入門 - 新知識 (その10) 一地下水のシミュレーションー、農業土木学会誌、5512、 $65 \sim 72$.

P.S. フヤコーン・G.F. ピンダー〔赤井浩一訳監修〕(1988) : 『地下水解析の基礎と応用 (上下巻)』現代工学社、 472p.

古市 徹・林田貴範・真柄泰基（1990）：河川を考虑した 地域地下水污染の解析、地下水学会誌、32-2、71 80. 古野邦雄・高中二三夫 - 佐藤健司 - 榆井 久 (1991) : 卜 リクロロエチレンによる地下水污染シミュレーション、 第 1 回環境地質学シンポジウム講演論文集、87 90.

C.A.ブレビア〔神谷紀夫・田中正隆・田中喜久雄訳〕 (1980)：「境界要素法入門』培風館、178p.

水収支研究グループ (1976)：『地下水盆の管理』東海大 出版、242p.

村田健郎·名取 亮·唐木幸比古（1990）：『大型数值シ ミュレーション』岩波書店、293p.

矢川元基・兽根田直樹 (1991)：『パラレルコンピューティ ング』培風館、134p.

山本正樹・中井泰明・村上安範 (1990)：『トランスピュー 夕入阴』日刊工業新聞社、271p.

Anderson, M.P. (1984) : Movement of Contaminants in Groundwater: Groundwater Transport-Advection and Dispersion, in Groundwater Contamination, National Academy Press, $37 \sim 45$.

Bear, J. and A. Verruijt (1987) : Modeling Groundwater flow and Pollution, D. Reidel Publishing Co., 414p.

Celia, M.A., L.A. Ferrand, C.A. Brebbia, W.G. Gray and G.F. Pinder eds. (1988) : Computational Methods in Waterr Re. sources, Vol. 1, 2, Proceedings of the 7th International Conferece, MIT, USA, June 1988, Elsevier Science Publishers, 388p. \& 466p.

Johnson, P.C., M.K. Kemblowski and J.D. Colthart (1990) : Quantitative Analisys for the Cleanup of HydrocarbonContaminated Soils by In-Situ Soil Venting, Groundwater, $28-3,413 \sim 429$.

Pickens, J.F. and G.E. Grisak (1981) : Scale-Dependent Dispersion in a Stratified Aquifer, Water Resour. Res., $17-$ 4, 1191 1212.

Pinder, G.E. and W.G. Gray (1977) : Finite Element Simulation in Surface and Subsurface Hydrology, Academic Press, 295p.

Remson, I., G. Hornberger and F. Molz (1971) : Numerical Methods in Subsurface Hydrology, Wiley-Interscience, 389p.

Yeh, W. W-G. (1988) : Review of Parameter Identification Procedures in Groundwater Hydrology: The Inverse Problem, Water Resour. Res., 22-2, 95 108.

(受付：1992年 1 月20日、受理：1992年 1 月31日） 